\title{
位相特性の変化が構造物の非線形応答に与える 影響把握のための基礎的検討
}

\author{
坂井 公俊 1 室野 剛隆 2 \\ 1正会員 （公財）鉄道総合技術研究所 構造物技術研究部（三185-8540 東京都国分寺市光町2-8-38） \\ E-mail: ksakai@rtri.or.jp \\ 2正会員（公財）鉄道総合技術研究所 構造物技術研究部（干185-8540 東京都国分寺市光町2-8-38） \\ E-mail: murono@rtri.or.jp
}

\begin{abstract}
位相の不確定性が構造物の非線形応答に与える影響を把握することを目的として，想定される範囲内の 位相特性と同一の弾性加速度応答スペクトルを有する時刻歴波形を多数作成し, 各波形の構造物非線形応 答量の変化について検討を行った。その結果, 同一の弾性加速度応答と想定規模より算定される位相特性 を有する時刻歴波形であっても, 位相の変化によって非線形応答が大きく変化すること, サイト特性の群 遅延時間が大きくなるほど非線形応答量が小さくなること，震源特性としてディレクティビティーの影響 が大きな地点ほど非線形応答が大きくなることなどが明らかになった．最後に今回得られた知見を踏まえ て, 位相特性の変化を考慮した設計地震動の選択例として, 今回作成した地震動群の中から一定非超過確 率を満足する時刻歴波形を抽出した.
\end{abstract}

Key Words : phase spectrum, source effects, local site effects, demand yield seismic coefficient spectrum, structural response

\section{1. はじめに}

地震学における強震動予測研究発展の成果として, 近 年では構造物の耐震設計に用いる地震作用に, サイト依 存の地震動が用いられる機会が多くなっている例えは112). ところが断層の破壞開始点やアスペリティ位置等の微視 的震源特性は，現時点では確定的に与えることが出来ず， 考えられる組み合わせを網羅的に設定し，各ケースに対 して地震動を作成し，構造物に影響の大きな1波もしく は数波を最終的な設計地震動として与えることになる. こういった場合の波形選択方法としては, 弾性加速度応 答スペクトルに基づいている場合が多いと考えられる. 構造物の非線形応答にまで踏み込んだ設計地震動の設定 に関する検討が行われた例も存在する例えば3 ものの，現 時点ではこれらの結果を一般化するには至っていない．

またこれとは別に，設計地震動として全国で標準的に使 用可能な弾性加速度応答スペクトルを設定し，この地震 動に基づいて耐震設計を行うという手続きも行われてい る例えば45)。、ずれにしても設計地震動を選択，設定する 場合には, 弾性加速度応答スペクトルが基準となってい る場合が多い。

一方で構造物の非線形応答を考えた場合，同一の弹性
加速度応答スペクトルを持った波形であっても位相の設 定方法によって応答值が大きく異なることは明らかであ る. そのため設計地震動を設定する際の位相特性の設定 は非常に重要な要素となる. このような背景のもとで, 筆者らは震源，伝播経路，サイトの各特性を考慮した位 相スペクトル算定を行うための一連の検討を行っている 6-8)．本手法を用いることで，各特性を考慮した地震波 形をシミュレートすることが可能であるものの，位相は 一義的に設定されるわけではなく, ある程度の幅（不確 定性）を持った形で表現されている. そのため得られた 時刻歴波形を入力した場合の構造物応答にもある程度の 幅が含まれるものと考えられるが，応答変化の程度や， どの計算条件で応答が大きくなるのか，といった検討は 行われていない，そこで本研究では提案手法が有寸る位 相の不確定性が構造物応答に与える影響について検討を 行う.

具体的な検討方法としては，筆者らが提案している位 相スペクトル算定手法8)を用いて，対象とする地震規模， 震源距離, 地盤条件の中で起こりうる地震動位相を多数 作成する. この地震動位相を有し, かつ同一の弾性加速 度応答スペクトルを有する時刻歴波形を作成する，得ら れた時刻歴波形を用いた構造物の非線形応答解析を実施 
することで, 構造物応答の変化の議論を行う.

ここで今回対象とする地震としては，鉄道構造物にお ける安全性を照査するための標準的な地震動（L2地震 動） 5する。.つまり, 内陸活断層の地震として, $\mathrm{Mw}=7.0$ の地震が直下で発生する場合の地震動（これを 以降ではスペクトルIと呼ぶ) と, 海溝型の地震として, $\mathrm{Mw}=8.0$ の地震が距離 $60 \mathrm{~km}$ の地点で発生する場合の地震 動（同，スペクトルI）の2タイプの地震を対象とする また対象地盤は，工学的基盤面（耐震設計上の基盤面， $\mathrm{Vs}=400 \mathrm{~m} / \mathrm{s}$ 程度）とする. これらの想定地震に対する弾 性加速度応答スペクトルとして, 図-1に示すスペクトル が提案されている.

\section{2. 位相のモデル化}

ここでは，震源特性，伝播経路特性，サイト特性を考 慮した位相スペクトル算定手法 ${ }^{8}$ について概略的に述べ る. まず地震動 $O(t)$ は, 震源特性 $S(t)$, 伝播経路特性 $P(t)$, サイト特性 $L(t)$ の積によって表現することが出 来る. この時, そのフーリエ変換は式(1)のように表わ される ${ }^{10)}$.

$$
O(\omega)=
$$

$$
S(\omega) \cdot P(\omega) \cdot L(\omega) \cdot \exp \left\{i\left(\phi^{S}(\omega)+\phi^{P}(\omega)+\phi^{L}(\omega)\right)\right\}
$$

ここで, $S(\omega), P(\omega), L(\omega)$ はそれぞれ震源特性，伝播経 路特性, サイト特性のフーリエ振幅, $\phi^{S}(\omega), \phi^{P}(\omega)$, $\phi^{L}(\omega)$ は各特性のフーリエ位相である.つまり, 地震動 位相 $\phi^{\circ}(\omega)$ は各特性の位相の線形和で表現される.さら に地震動の群遅延時間 $t_{g r}^{o}(\omega)$ は位相の微分であるためこ の線形関係はそのまま保存され以下のように表現するこ とが出来る.

$$
t_{g r}^{O}(\omega)=t_{g r}^{S}(\omega)+t_{g r}^{P}(\omega)+t_{g r}^{L}(\omega)
$$

この群遅延時間 $t_{g r}^{o}(\omega)$ が各振動数ごとに正規分布に従う とした時, 群遅延時間の平均值 $\mu_{\text {tgr }}^{O}(\omega)$, 標準偏差 $\sigma_{\text {tor }}^{O}(\omega)$ についても次式のように震源, 伝播経路, サイ トの各特性に分離される.

$$
\begin{gathered}
\mu_{\operatorname{tgr}}^{O}(\omega)=\mu_{\operatorname{tgr}}^{S}(\omega)+\mu_{\operatorname{tgr}}^{P}(\omega)+\mu_{t g r}^{L}(\omega) \\
\left(\sigma_{\operatorname{tgr}}^{O}(\omega)\right)^{2}=\left(\sigma_{\text {tgr }}^{S}(\omega)\right)^{2}+\left(\sigma_{\operatorname{tgr}}^{P}(\omega)\right)^{2}+\left(\sigma_{\operatorname{tgr}}^{L}(\omega)\right)^{2}
\end{gathered}
$$

このうち, 震源項 $\mu_{t g r}^{S}(\omega), \sigma_{t g r}^{S}(\omega)$ についは, 断層 の破壊過程に従ったインパルス列の重㸚合わせで表現す ることとしたの). また伝播経路特性 $\mu_{t g r}^{P}(\omega), \sigma_{t g r}^{P}(\omega)$, サ イト特性 $\mu_{t g r}^{L}(\omega), \sigma_{t g r}^{L}(\omega)$ にいては, 観測記録に基づ いた群遅延時間の推定式を提案している

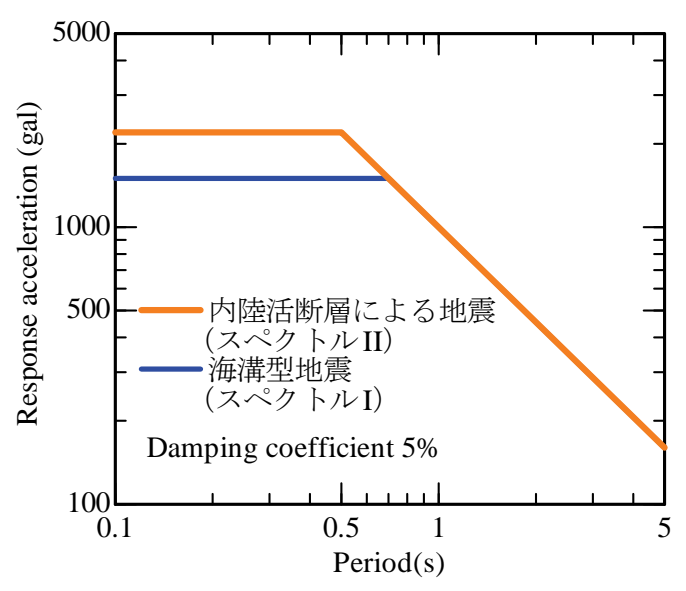

図-1Ｌ2地震動の標淮的な 弾性加速度応答スペクトル

\section{3. 時刻歴波形の作成}

\section{(1) 震源特性の設定}

位相の震源特性は, 断層の破壊過程と対象地点の位置 関係によって大きく変化するものと考えられる. そこで 今回は図-2（スペクトルII）, 図-3（スペクトルI）に示 すような複数の断層の破壊過程と観測点を設定した.

スペクトルIでは観測点を断層の周りに8地点配置 （Site A H） し，6パターンのアスペリティ, 破壊開始点 の位置（Case 1 6）を設定し，計8×6=48パターンについ て震源特性の評価を行った. 断層は傾斜角90度とし, 断 層上面を地表面から深さ3kmの位置に設定した，その他 巨視的震源特性および微視的震源特性については, 過去 の内陸活断層による地震をもとに提案されている手法 11112)に基づき設定している. アスペリティは2つ設定し, 破壞開始点付近に大きなアスペリティ1と，それより上 部にサイズの小さなアスペリティ2を配置した．破壊は 破壊開始点より同心円状に $2.8 \mathrm{~km} / \mathrm{s}$ で広がり，アスペリテ イ内の破壊は全体の破壊開始点に最も近いコーナーから 同心円状に進行するものとした. また今回の位相モデル 化は，断層タイプ，震源からの放射特性等は無視してい るため, 断層設定の際にこれらの条件は考慮していない． スペクトルでは図-3のように $90 \mathrm{~km} \times 100 \mathrm{~km} の$ 震源域が 傾斜角 $18^{\circ}$ で陸地に向かって沈み込むような状況を想定 し, アスペリティのサイズ, 配置として2ケースを設定 した。 これは過去に発生したM8級の地震である2003年 十勝沖地震における特性化震源モデル ${ }^{13)}$ を基本として設 定したものである。観測点は陸地側に21地点（Site $\mathrm{A} \sim \mathrm{U})$ 配置し, 計 $2 \times 21=42$ パターンの震源特性を評価し た. 断層の破壊伝播等については，スペクトルПの場合 と同様の条件で設定している.

以上の条件設定により得られた結果は想定しうる地震 


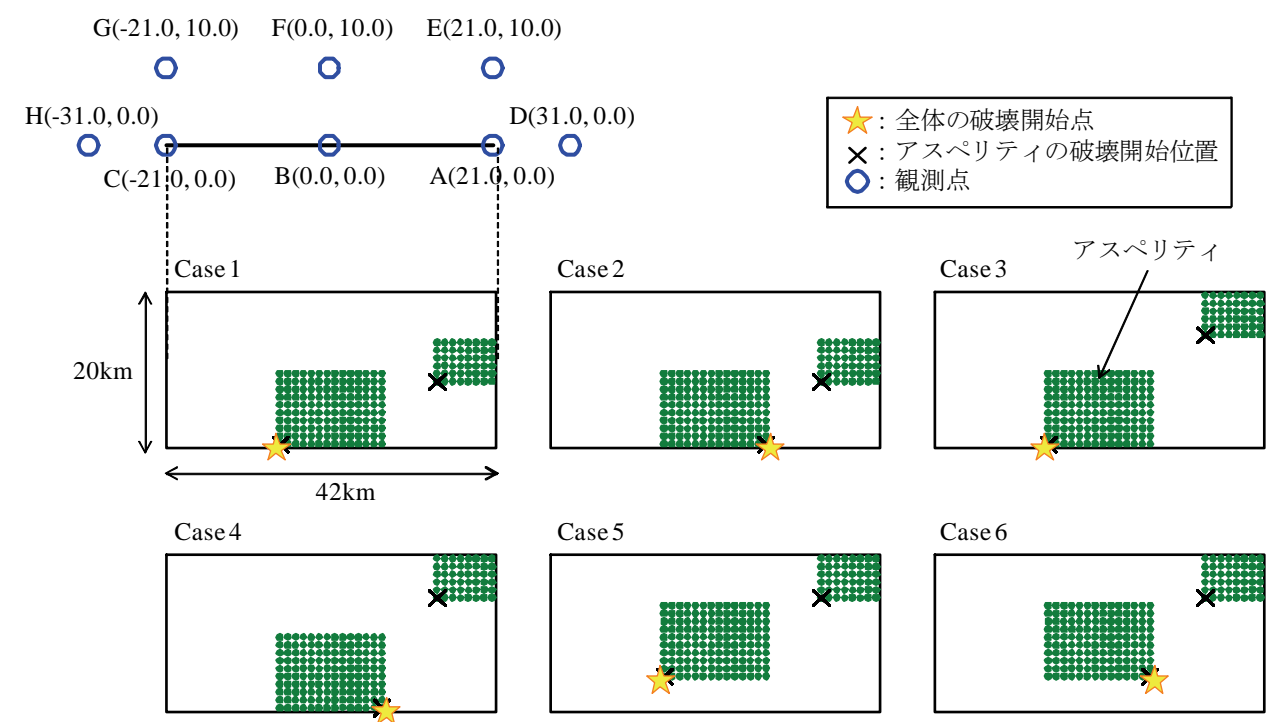

図-2＼cjkstart観測点，断層の破壊開始点，アスペリティ位置の配置（スペクトルI）
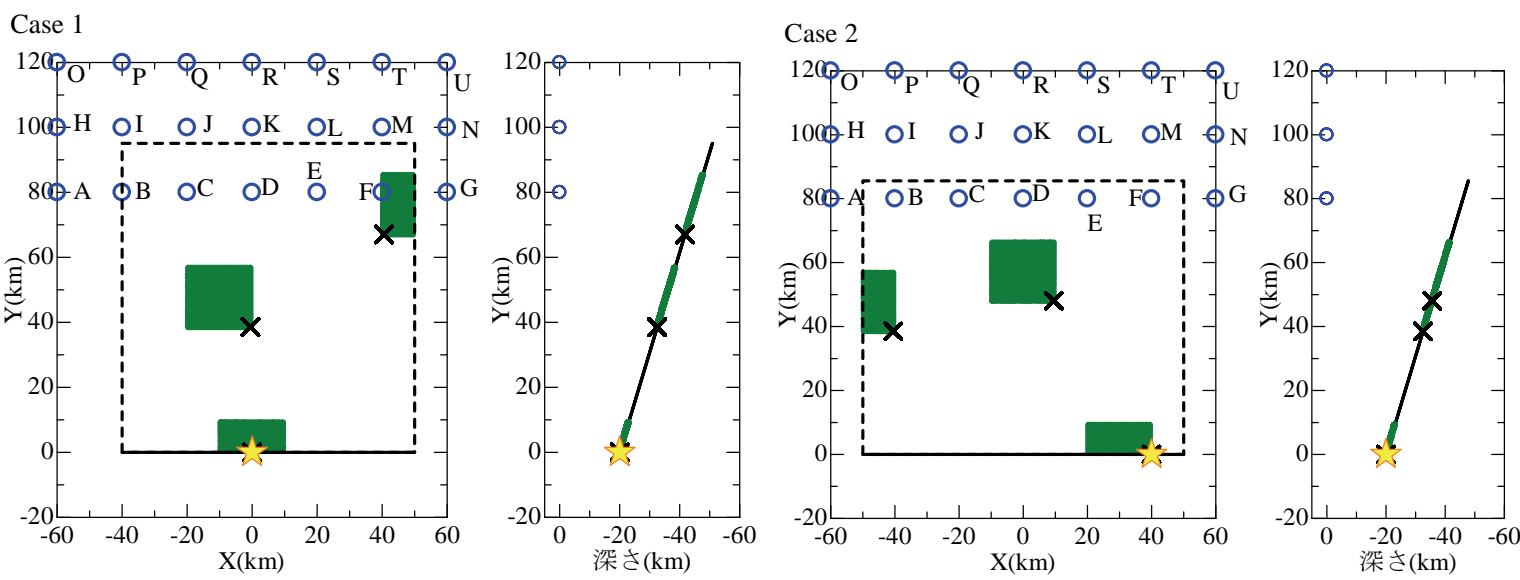

図-3＼cjkstart観測点，断層の破壊開始点，アスペリティ位置の配置（スペクトルI）
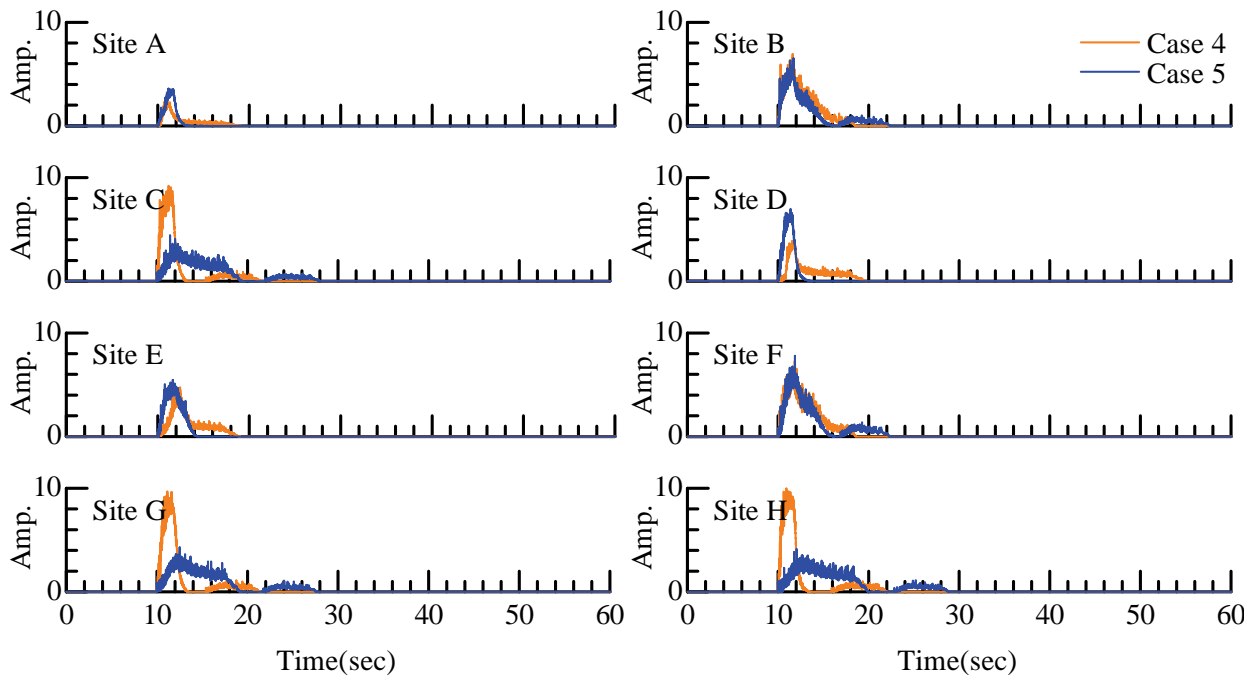

図-4＼cjkstart位相の震源特性評価の例（スペクトルI）

の全条件を網羅しているものではないが，震源域の設定 に対してある程度広がりを持った観測点の設定をしてい ることから，断層傾斜と観測点の位置関係や断層の破壞 伝播効果をある程度の範囲で検討したものと考えている.
震源特性評価の例として，スペクトルாにおけるCase4, Case5において算定されたインパルス列算定結果をまと めて図-4に示寸。この結果から，本手法によって破壊の 指向性を適切に表現できていることが分かる，例えば 

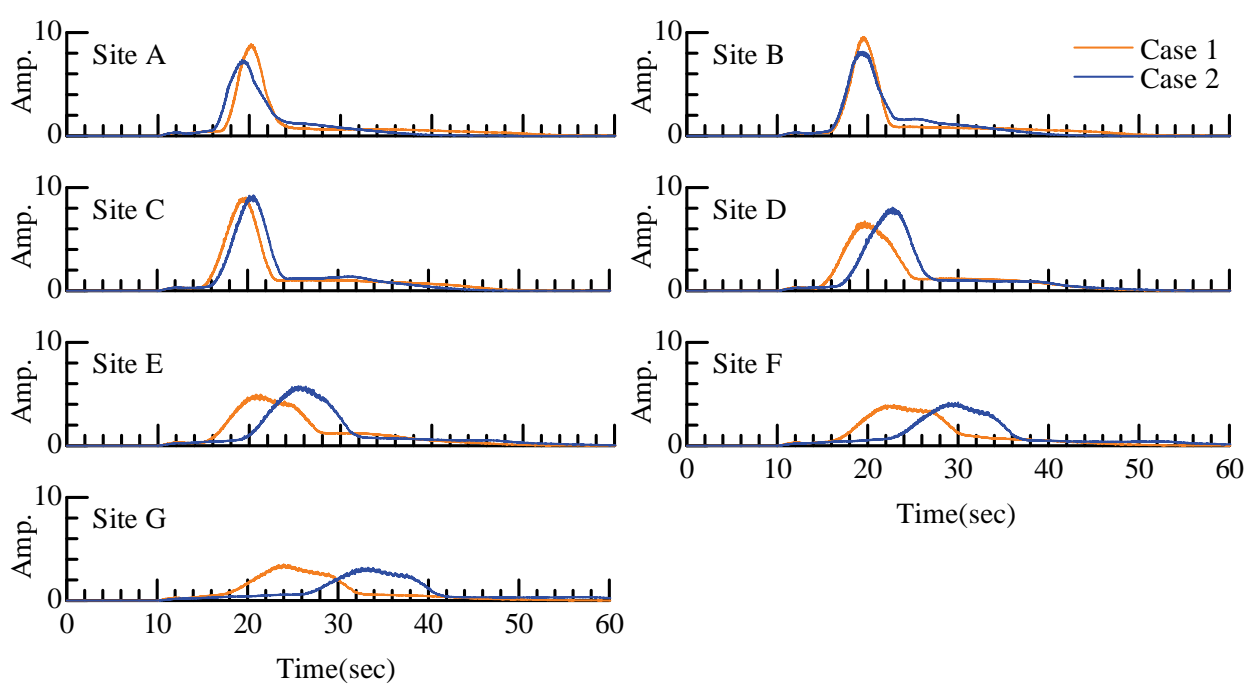

図-5 位相の震源特性評価の例（スペクトルI）

Site CではCase4のアスペリティ1は破壊が向かってくる方 向，Case 5では破壊が遠ざかる方向に位置している，そ の影響を受けて, Case 4では継続時間が短く, Case 5では 継続時間が長くなっている.また，Case5のSite A PSiteD はアスペリティ1, 2ともに破壊が向かってくる方向に位 置しているため, インパルス列としても一つにまとまっ た形状をしていることが分かる。こういった影響を受け て，最終的に得られる時刻歴波形の継続時間や波形の形 状等が変化することが期待される.さらにスペクトルI におけるインパルス列評価の例を図-5に示すが，断層サ イズの違いによって，スペクトルாにおける結果と比較 してインパルス継続時間が長くなっていることが分かる. これより，地震規模が大きくなることによる地震動継続 時間の増大を適切に表現出来ていることが期待される.

\section{（2）伝播経路特性，サイト特性の設定と地震動合成の 条件}

伝播経路特性は次式で表わされるように，平均值 $\mu_{t g r}^{P}(\omega)$, 標準偏差 $\sigma_{t g r}^{P}(\omega)$ ともに震源距離 $R$ の2乗に比 例すると仮定した上で, 各振動数毎の回帰係数 $\beta_{1}(\omega), \beta_{2}(\omega)$ を評価している

$$
\begin{aligned}
& \mu_{\operatorname{tgr}}^{P}(\omega)=\beta_{1}(\omega) \cdot R^{2} \\
& \sigma_{\operatorname{tgr}}^{P^{2}}(\omega)=\beta_{2}(\omega) \cdot R^{2}
\end{aligned}
$$

この震源距離 $R$ については，図-1に示すL2地震動の 弾性加速度応答スペクトル設定時に想定している震源距 離（スペクトルII : 3km，スペクトルI : 60km） 9)を用い て評価した：ここでスペクトルIIは，Mw=7.00地震が直 下で発生した場合を想定しているが，今回の計算におけ る震源距離は3kmに設定している. これは地表面数kmに は地震を発生させにくい領域があるとされており例えば14),
地表に断層面が現れている場合でも，この範囲では応力 降下がほとんど発生していないことが指摘されているこ とを加味したものである.

サイト特性については，以下のように設定した。 サイ 卜特性の群遅延時間は次式のように対象地盤のせん断弾 性波速度と関連付けてモデル化している8).

$$
\begin{aligned}
& \mu_{\operatorname{tgr}}^{L}(\omega)=\gamma_{1}(\omega) \cdot\left(3000-V_{S}\right)^{2} \\
& \sigma_{\operatorname{tgr}}^{L 2}(\omega)=\gamma_{2}^{2}(\omega) \cdot\left(3000-V_{S}\right)^{2}
\end{aligned}
$$

ここで $V_{S}$ は観測地点直下地盤のせん断弾性波速度 $(\mathrm{m} / \mathrm{s}), \gamma_{1}(\omega), \gamma_{2}^{2}(\omega)$ は回帰係数である. 式(5)において 群遅延時間のサイト特性は，せん断弾性波速度が $3 \mathrm{~km} / \mathrm{s}$ となるような岩盤（地震基盤）上においてはゼロとなる ように設定しており，それよりも軟弱な地盤では対象地 点直下の地盤 $V_{S}$ によって変化するように設定している. これは観測記録に基づき設定したものであるが，式(5) は大きなバラツキを持っていることが分かっている.こ れは実際のサイト特性とは，地震基盤から対象地点の間 に存在する堆積構造の影響を表現したものであり，対象 地点直下の地盤特性だけで決定されるものではないため であると考えられる. そこで今回は式(5)の $\mu_{t g r}^{L}(\omega)$ と $\sigma_{\text {tgr }}^{L}{ }^{2}(\omega)$ を1.0倍 0.1 倍まで0.1刻みで10通りの変化をさせ ることで，位相サイト特性の変化を簡易的に検討するこ ととした. また，設定した $\mu_{t g r}^{L}(\omega)$ と $\sigma_{t g r}^{L}{ }^{2}(\omega)$ となる正 規分布に従った群遅延時間を発生させる際には，各条件 ごとに10通りの初期乱数を設定した.

最終的に発生させた群遅延時間のセットは，スペクト ルIでは4800セット（震源特性6ケース×観測点8ケース× サイト特性の変化10个ース×サイト特性の初期乱数10个 一ス），スペクトルでは4200セット（震源特性2ケース 観測点21ケース×サイト特性の変化10ケース×サイト特 性の初期乱数10ケース）である.

以上の流れに従うことで，各ケースごとの位相特性 

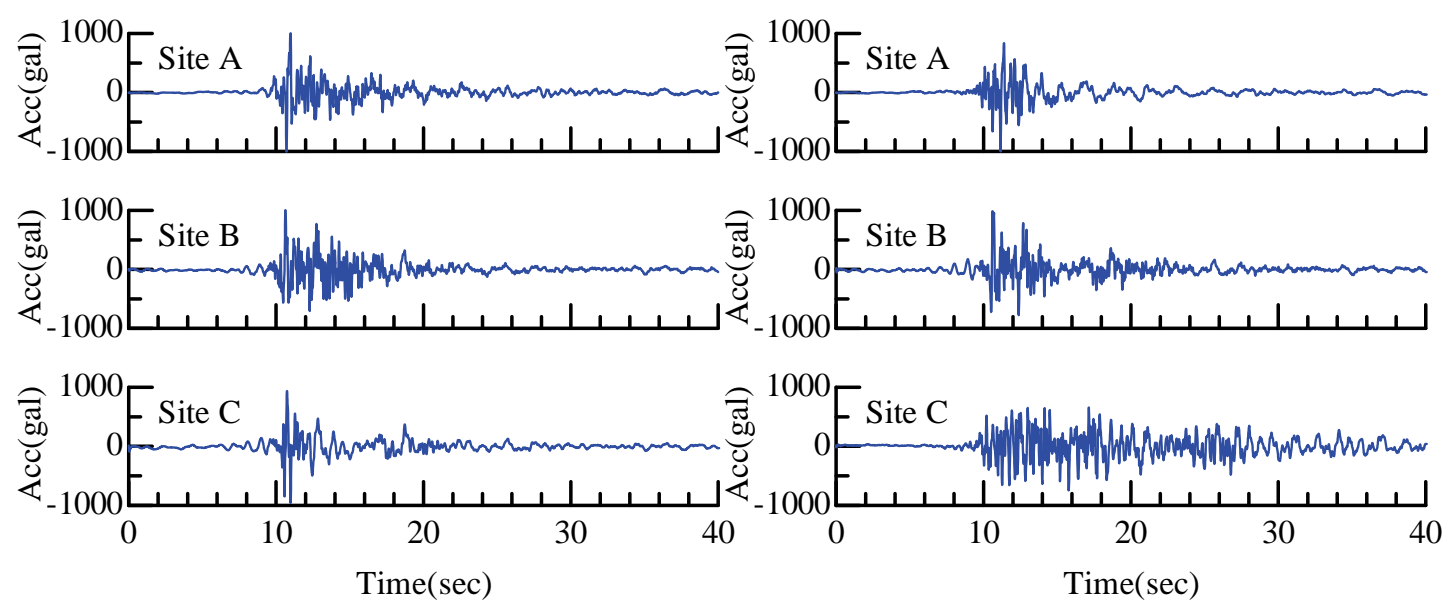

(a)Case4

(b) Case 5

図-6＼cjkstart震源特性の違いによる波形形状の変化の例（スペクトルII，サイト特性0.1倍）
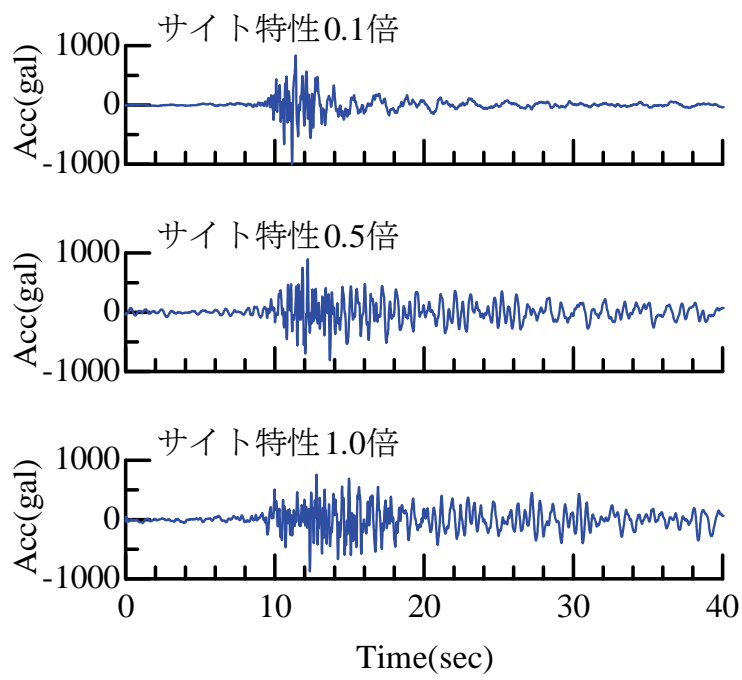

図-7サイト特性の違いによる波形形状の変化の例 (スペクトルII, Case 5, Site A)

$\phi^{\circ}(\omega)$ が設定された. 続いて振幅特性は図-1の弾性加速 度応答スペクトルにフィッティングさせることで与える こととした. フィッティングの方法としては，フーリエ 振幅スペクトルは非減衰の速度応答スペクトルと概ね一 致するという関係 ${ }^{15}$ 用いて初期のフーリエ振幅スペク トル $A_{0}(\omega)$ を設定し, 繰り返し計算により振幅を調整す ることで, 目標応答スペクトルに適合させた ${ }^{16}$. 得られ た時刻歴波形の例を図-6（震源特性の影響），図-7（サ イト特性の影響) に示寸。これらの結果より, 各特性の 影響を受けて波形の最大加速度や継続時間が大きく変化 していることが分かる.

\section{4. 構造物応答の検討}

前節で設定された多数の地震動波形は全て同一弾性加
速度応答スペクトルを持った断層直上で想定される地震 動である.つまり弾性加速度応答スペクトルを基準とし て設計地震動を選択した場合に，いずれも選択される可 能性のある地震動である.この各種波形が構造物の非線 形応答にどのような影響を与えるのか考察を行う.

検討を行う手法として, 各波形の所要降伏震度スペク トルを算定し，構造物を所要の性能（応答塑性率）に収 める際に要求される降伏震度の違いを評価することとし た. この所要降伏震度スペクトルは非線形応答スペクト ル ${ }^{17} の 一$ 種であり, 構造物の応答塑性率ごとに固有周期 と降伏震度との関係を図化したものである ${ }^{18)}$. この所要 降伏震度スペクトルを用いることで，ある周期，降伏震 度を有する構造物の応答塑性率を簡便に求めることが可 能である。ここで言う応答塑性率とは, 最大応答変位 $\delta_{\text {max }}$ を降伏変位 $\delta_{y}$ で除したものである. 所要降伏震度 スペクトル作成条件として，骨格はバイリニアモデル， 履歴はクラフモデル ${ }^{199}$ とする. 第1勾配に対する第2勾配 の比は 0.05 , 除荷時の剛性低下指数は 0.2 と, 減衰定数 は周期に依存させず一定の0.05を用いた ${ }^{20}$. 以上のよう に，今回は鉄道RC構造物の設計で一般的に使用されて いるモデルを使用しているため, 本結果の適用範囲とし ては, 設計で考慮している領域, つまり構造物の応答が 安定ループに留まっている領域となる.

\section{（1）全ての位相特性の変化を含んだ応答のバラツキ}

全ケースの所要降伏震度スペクトルを算定し，まとめ たものを図-8（スペクトルII），図-9（スペクトルI）に 示寸. なお計算寸る応答塑性率 $\mu$ としては，1 (弾性)， 2, 4,8の4種類とした. これらの図より以下のことが分か る.

まず各図(a)の $\mu=1$ の結果であるが，平均值は図-1の 弾性加速度応答スペクトルとほぼ一致するものの, 各結 果には多少の違いが発生していることが分かる。これは 弾性加速度応答スペクトルにフィッティングさせる際に, 


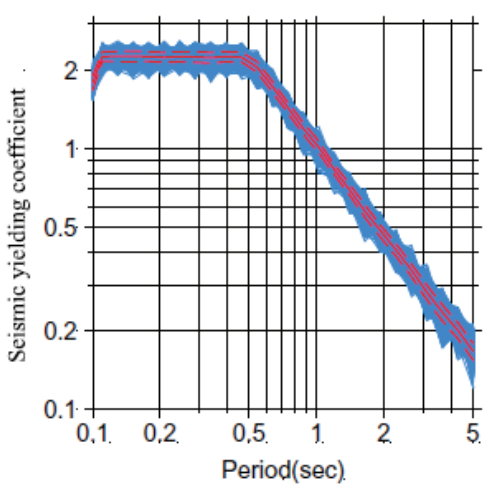

(a) 応答塑性率 $\mu=1$ の場合

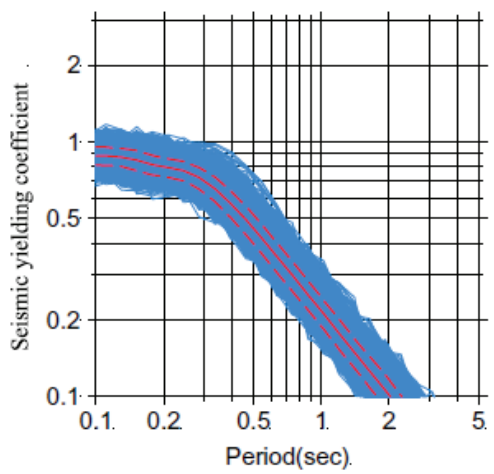

(c) $\mu=4$ の場合

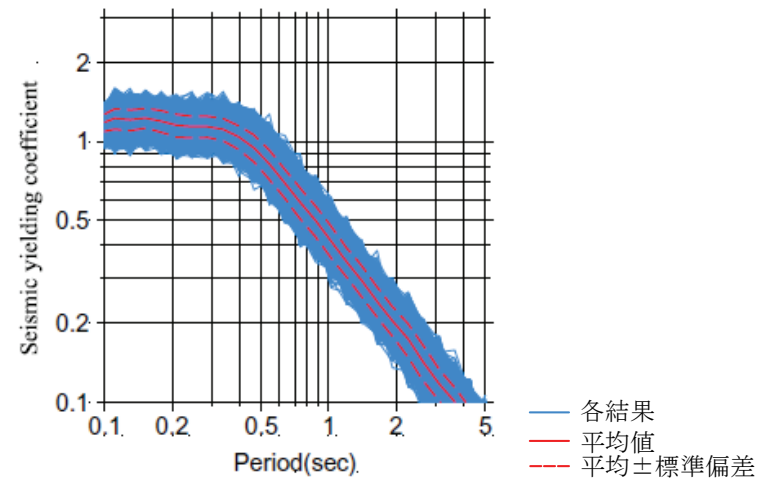

(b) $\mu=2 の$ 場合

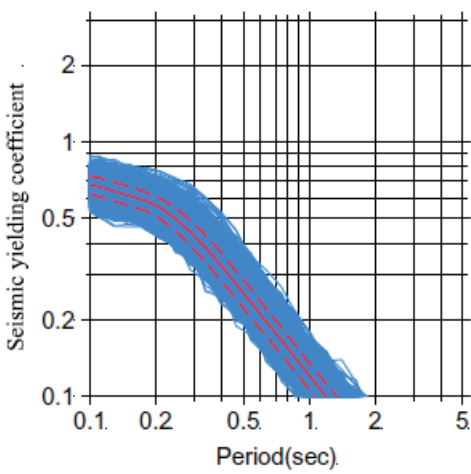

(d) $\mu=8$ の場合

図-8 所要降伏震度スペクトル算定結果（スペクトルII）

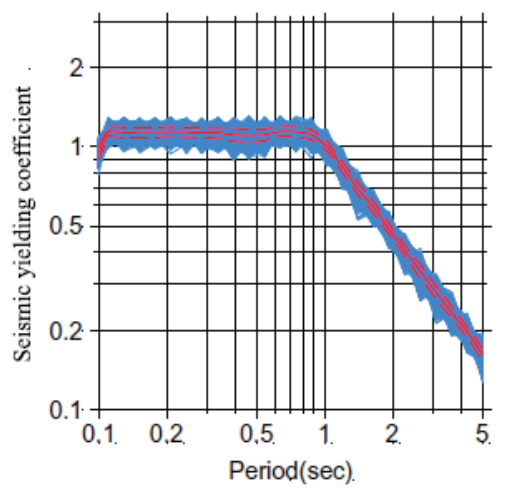

(a) 応答塑性率 $\mu=1$ の場合

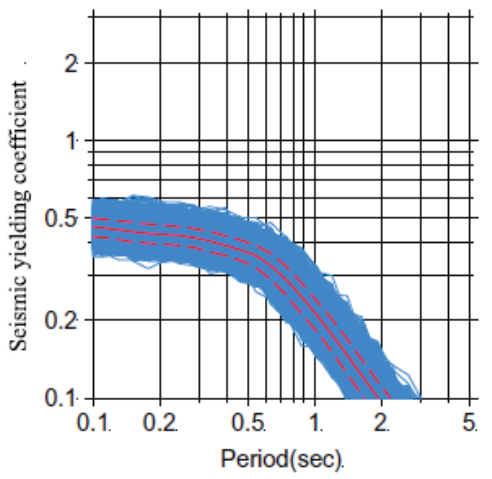

(c) $\mu=4$ の場合

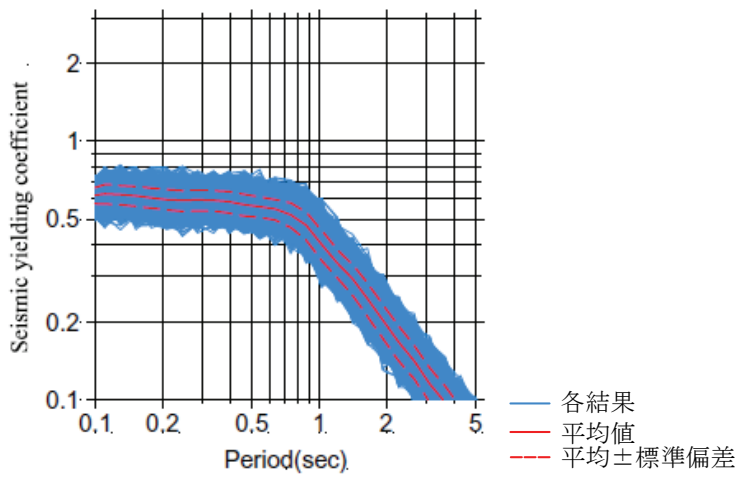

(b) $\mu=2$ の場合

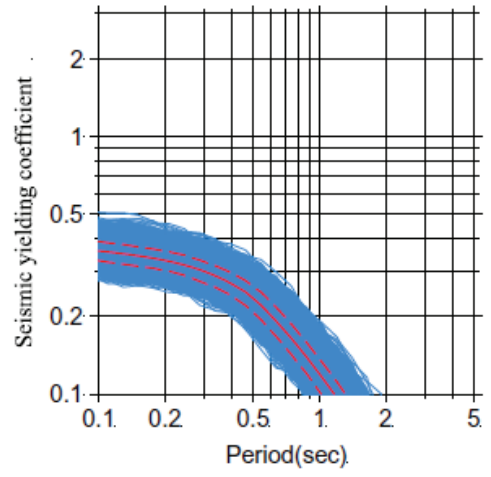

(d) $\mu=8$ の場合

図-9 所要降伏震度スペクトル算定結果（スペクトルI） 


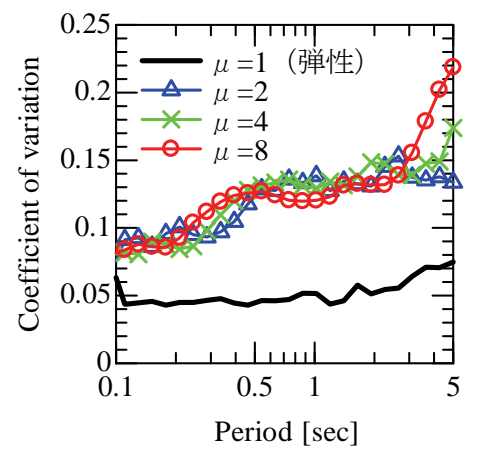

(a)スペクトルII

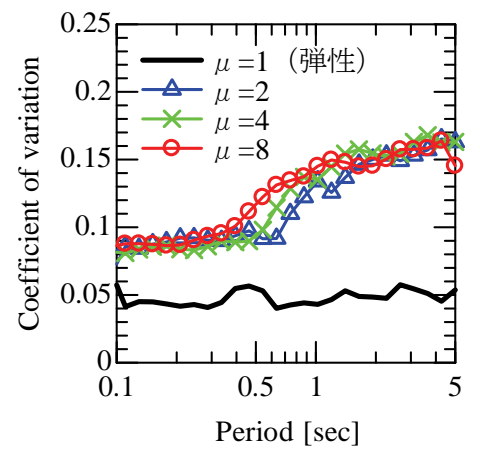

(b)スペクトルI

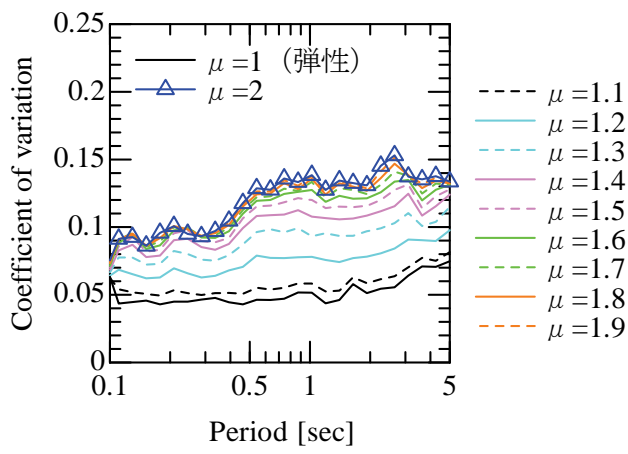

(c)スペクトルII $(\mu=1.0$ 2.0の詳細 $)$

図-10 応答塑性率の変化に伴う変動係数の変化

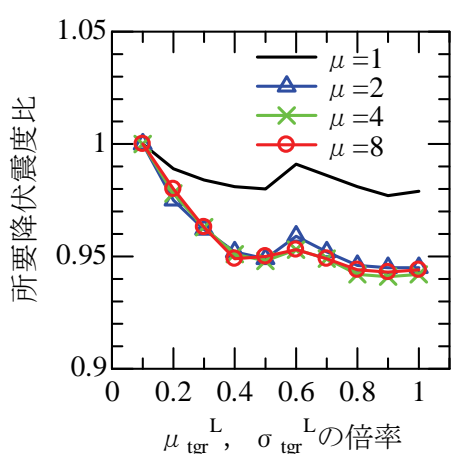

(a) 周期 $0.05-0.158(\mathrm{sec})$ の平均

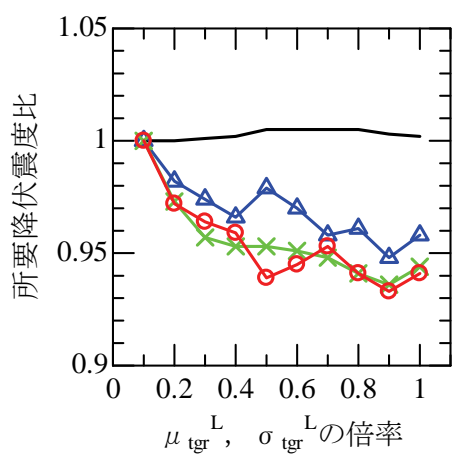

(c) 周期 0.50-1.58(sec)の平均

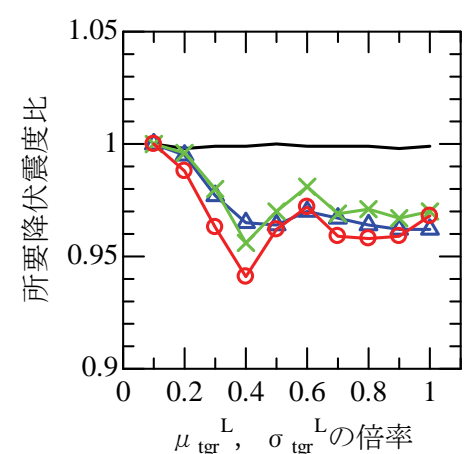

(b) 周期0.158-0.50(sec) の平均

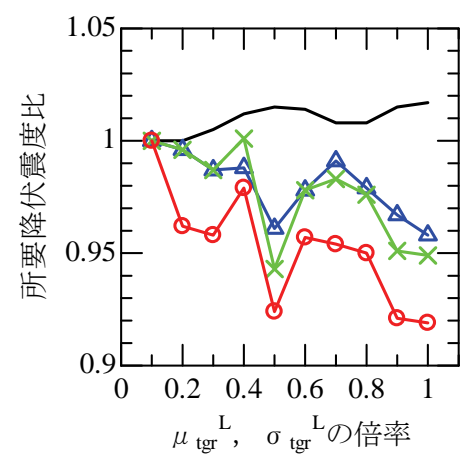

(d) 周期1.58-5.0(sec)の平均

図-11 位相のサイト特性のバラツキが構造物の所要降伏震度に与える影響（スペクトルI）

完全には一致させておらず，目標値との誤差をある程度 許容（実際には5\%）しているために発生したバラツキ である.このバラツキは $\mu>1$ の結果に対しても含まれ ていることに注意が必要である，そのため，位相特性の 影響を考察する際には, この振幅特性のバラツキ (弾性 応答時に有するバラツキ）を差し引いて検討を行う。

各図の(a) (d)を比較すると，(a)の $\mu=1$ の結果と比較 して, (b) (d)の $\mu=2 \sim 8$ の結果は応答の変動が大きく なっていることが分かる．例えば図-8 (c)を例に挙げて 見ると, 周期 0.5 秒, $\mu=4$ の構造物を設計寸る場合に 構造物に要求される降伏震度は0.35 0.70までの範囲を持 っている.

続いて応答塑性率，周期の変化に伴う応答の変動を定 量的に表現するために, 各応答塑性率 $\mu$ において周期 ごとの変動係数を算定した（図-10(a), (b)）。この図にお いて，(a)がスペクトルIの結果，(b)がスペクトルの結果 である．前述したとおり， $\mu=1$ の変動係数（約0.05） はスペクトルフィッティング時の誤差であり, 構造物が 非線形化することによる変動係数の変化は, これを差し 引いた值で評価する必要がある. 図-10より， $\mu=1$ と その他の結果で変動係数に大きな差があるが, $\mu=2,4,8$ の結果にはそれほど違いは見られない.この 結果は, 構造物が非線形応答寸る場合, その応答量の大 小にかかわらず，応答の変動は一定であることを示唆し ている.

この変化をもう少し詳細に分析するために，スペクト ルIの全波形に対して， $\mu$ を1.0 2.0まで0.1刻みで変化さ せて再計算した結果を図-10 (c)に示す。これより $\mu$ が2.0 


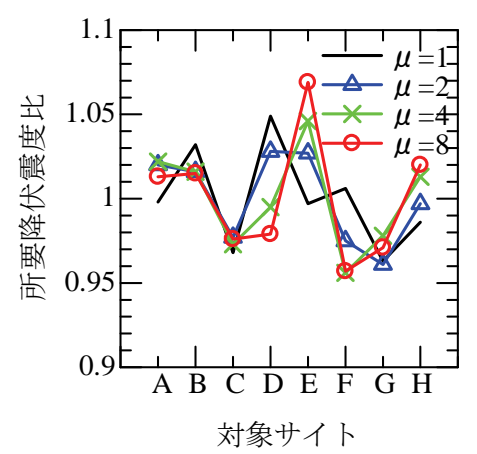

(a) 周期0.05-0.158(sec)の平均

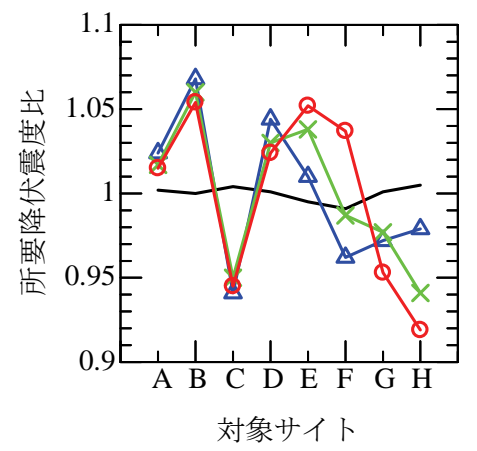

(c) 周期0.50-1.58(sec)の平均

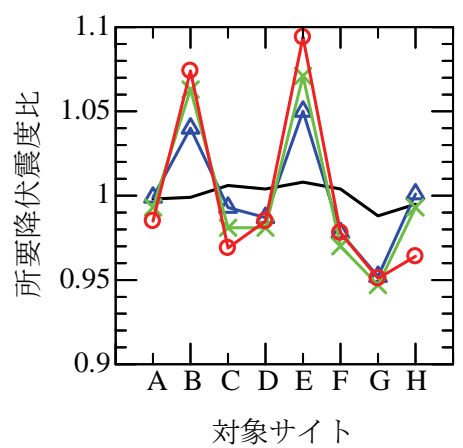

(b) 周期0.158-0.50(sec)の平均

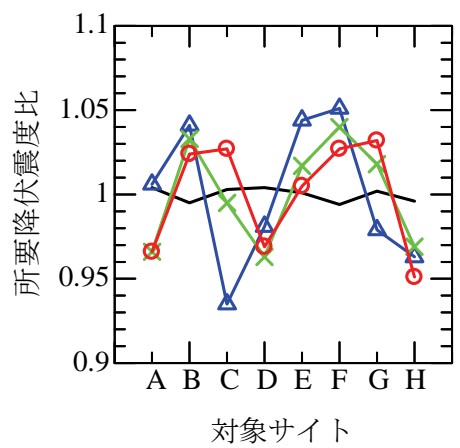

(d) 周期1.58-5.0(sec)の平均

図-12 位相の震源特性のバラツキが構造物の所要降伏震度に与える影響（スペクトルII）

以下の比較的小さい領域では応答の変動は一定ではなく, 応答塑性率が大きくなるにしたがって徐々に変動係数が 大きくなっていることが分かる．このように，応答塑性 率が大きくなることで応答の変動が増大寸るが, その増 大は，ある段階で頭打ちになる，という傾向は大変興味 深い結果である。これは降伏点を少し上回った場合の応 答でバラツキが大きくなることを示唆しているが，この 現象の細かなメカニズムについては今後さらに検討を行 う必要がある。ここで，一般的な鉄道構造物のL2地震 時における応答塑性率は概ね3.0 7.0程度であると考えら れるが，この範囲で想定される応答の変動は一定である と考えても問題ない，さらに図-10より，構造物の周期 が長くなるほど位相の変化に伴う応答の変動が大きくな る可能性があることも見て取れる.

\section{（2）サイト位相特性の変化が構造物応答に与える影響}

今回は位相のサイト特性の変化を群遅延時間の平均 $\mu_{t g r}^{L}(\omega)$ と標準偏差 $\sigma_{t g r}^{L}(\omega)$ を提案值の1.0倍 0.1倍する ことによって表現している.ここではこのサイト特性の 違いが構造物応答にどのような影響を与えるのかについ て考察を行う。まず提案值からの倍率毎に所要降伏震度 スペクトルを区分する（10分類）．次にスペクトルを計 算した周期（0.05 5秒）を対数軸で4分割し，各倍率， 各応答塑性率, 各周期区分ごとに所要降伏震度の平均值 を求める. 得られた平均所要降伏震度を倍率 0.1 の結果 でそれぞれ基準化し，サイト特性の変化に伴う所要降伏 震度の変化を求める. 得られた結果のうち, スペクトル
Iによるものを図-11に示す。スペクトルIにおける結果 はこれと同様の傾向を示しているため，省略する．図11の縦軸は, 所要降伏震度比の值が大きいほど降伏震度 の大きな構造物が要求されるとともに, 同一条件の構造 物においては応答が大きくなることを意味する.

応答塑性率 $\mu=1$ （弾性）の場合, 周期, 倍率によら ず概ね 1.0 となっていることが分かる。 これは全条件に おいて弾性加速度応答スペクトルにフィッティングさせ ているため当然の結果である. またこの結果より, フィ ッティング時の降伏震度の誤差平均值として, 最大 0.02 程度が存在していることも分かる。

続いて応答塑性率 $\mu=2,4,8$ の結果を見ると，全体的 に群遅延時間の倍率が大きくなるほど所要降伏震度比が 小さくなっていることが分かる.この傾向は構造物の周 期, 応答塑性率 $\mu$ の大小にかかわらず概ね同様である. これは構造物を非線形の領域まで考慮して設計する際に は，今回想定した範囲の位相のサイト特性の変化によっ て, 要求される降伏震度が5\%程度変化することを示唆 している.この值は前述した $\mu=1$ の時の誤差（0.02） と比較して, 明らかに大きな值である.

ただし，(d)に示寸構造物周期1.58〜 5.00秒，応答塑性 率 $\mu=8$ の結果では所要降伏震度比が他の結果よりも 小さく, かつ倍率の変化によって結果が大きく変化して いることが分かる.この要因の詳細については, 以下の ように推測される. まず, 群遅延時間の平均 $\mu_{\mathrm{tgr}}^{L}(\omega)$ と 標準偏差 $\sigma_{t g r}^{L}(\omega)$ はともに周期が長くなるほど大きく なる傾向があるために, 提案值の倍率が大きくなると, 


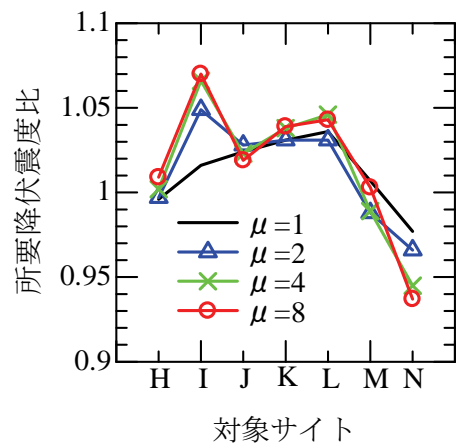

(a) 周期0.05-0.158(sec) の平均

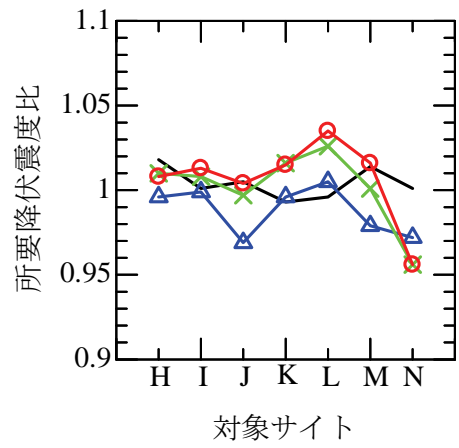

(c) 周期 0.50-1.58(sec) の平均

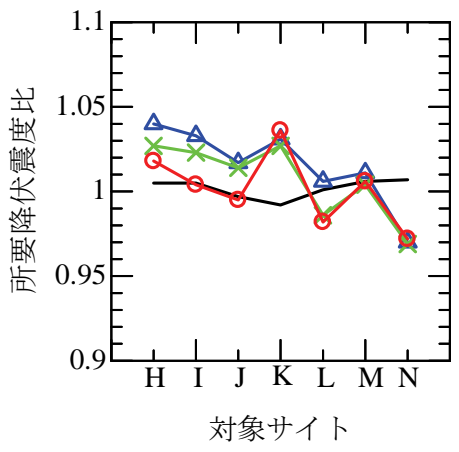

(b) 周期0.158-0.50(sec)の平均

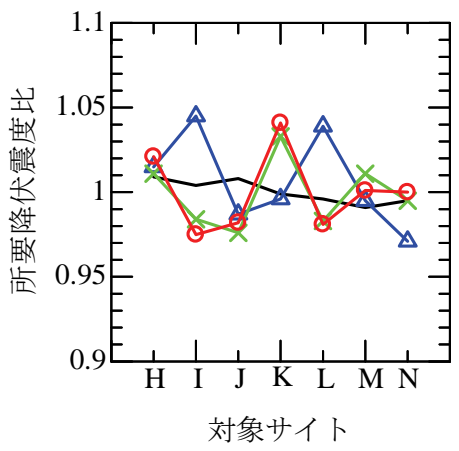

(d) 周期1.58-5.0(sec) の平均

図-13 位相の震源特性のバラツキが構造物の所要降伏震度に与える影響（スペクトルI）

$\mu_{\operatorname{tar}}^{L}(\omega), \sigma_{\operatorname{tar}}^{L}{ }^{2}(\omega)$ ともに30 40秒程度の值となる．その ため長周期側の群遅延時間が今回想定した地震の継続時 間（81.92秒）に対して大きくなりすぎている可能性が 考えられる．これらについては今後詳細な検討を行う必 要がある.

\section{(3) 震源特性の変化が構造物応答に与える影響}

続いて位相の震源特性の変化が構造物応答に与える影 響について考察を行う. 前節の検討より, 位相のサイト 特性は構造物応答に影響を与えることが分かっているた め，ここではサイト特性を固定（提案值の0.1倍）して 検討を行う．断層の破壊ケースとしては，スペクトルII では図-2のCase 5，スペクトルでは図-3のCase 2とした. 対象地点は，スペクトルIでは全地点，スペクトルでは サイトH Nとした。結果の整理方法は前節の図-11 と同 様である．ただしここでの基準降伏震度（所要降伏震度 比1.0）は，サイト特性を0.1倍とした場合の全地点での 所要降伏震度の平均値とした。得られた結果を図-12

(スペクトルII），図-13（スペクトルI）に示す.

この結果より, 地点ごとに所要降伏震度比が大きく変 化していることが分かる．ただし応答塑性率 $\mu=1$ の場 合は(a)の構造物周期が短い場合を除いて変動は小さく, $\mu>1$ の場合は応答塑性率の大小にかかわらず各サイト ごとの所要降伏震度比は概ね一致している.

また図-12のスペクトルIIでは，周期ごとに変動がある ものの，相対的にSite B, D, E, Fといった地点では所要降
伏震度比が大きく, Site C, G, Hでは小さくなる傾向が見 られる．前者は破壊が進行する方向であり，図-2の震源 特性を示寸インパルス列の継続時間が短い地点，後者は 破壊が遠ざかる方向に位置し，インパルス列の継続時間 が長い地点である。また図-13のスペクトルでは，大ま かな傾向として右下がりの傾向を示している. Site Hは 破壊が向かってくる方向，Site Nは破壊が遠ざかる方向 である。これらの結果は前節と同様に，波形の継続時間， 群遅延時間が短くなるほど非線形応答量が大きくなる傾 向があることを示している。これは今回想定したような 耐力劣化を起こさない範囲の構造物応答を考えた時には, 累積的な変形の増大よりもエネルギーの集中した1波に よる応答の影響がより大きいためであると考えられる. ただし，スペクトルのの地点毎の変化はスペクトルIと比 較して小さく，断層サイズ，震源距離の違いによって， 震源特性の影響度合いが変化することも確認できる.

さらにこの結果は工学的には, 震源距離, 地盤条件, 弾性応答量が等しい場合にも，断層との位置関係による 位相特性の変化によって, 構造物に要求される降伏震度 が1割程度変化することを示唆している.

\section{5. 各特性の変化を考慮した設計地震動の時刻歴 波形の選択の例}

構造物の而震設計に用いる標準的な設計地震動を考え た場合，弾性挙動のみならず非線形挙動に対しても応答 


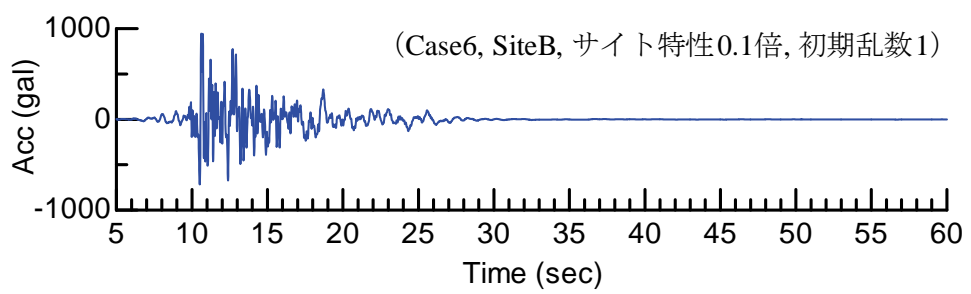

(a)スペクトルII

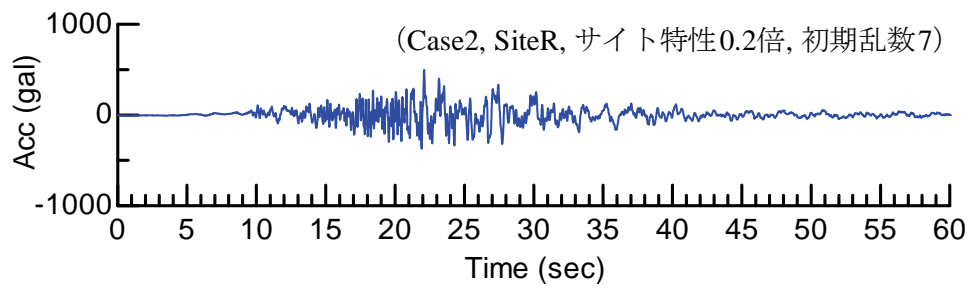

(b) スペクトルI

図-14 選択された時刻歴波形

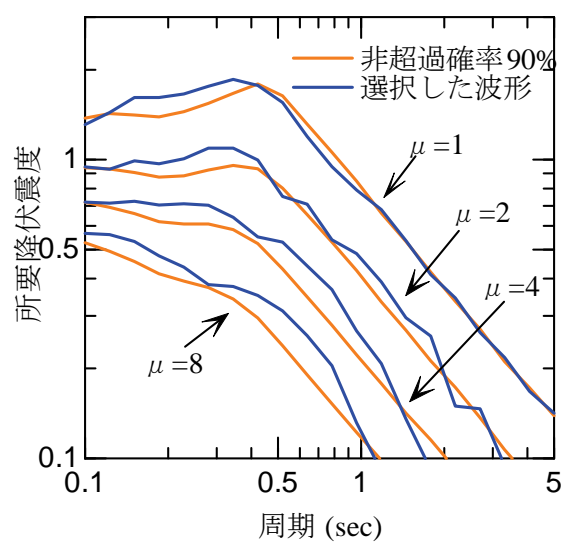

(a)スペクトルII

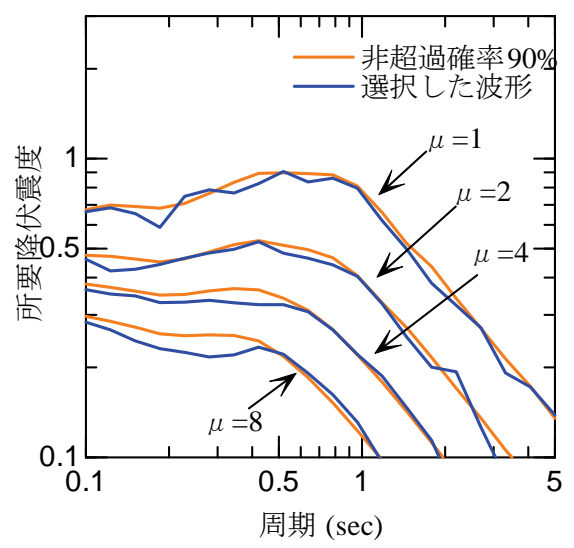

(b) スペクトル

図-15＼cjkstart選択された波形の所要降伏震度スペクトル $(\mu=1,2,4,8)$

が大きくなるような地震動となっていることが望ましい. ここで，弾性加速度応答スペクトルを設定する際には， 想定される地震動を非超過確率 90\%で包絡するような地 震動を設定している ${ }^{59)}$. そこで今回は，構造物の非線形 応答量としても，図-8，図-9の所要降伏震度スペクトル を各応答塑性率，各周期において非超過確率90\%で包絡 するような時刻歴波形を抽出することで，非線形応答と しても大きくなるような設計地震動を選択することが出 来るものと考えた.

この条件に基づき，図-8，図-9の全スペクトルの中か ら，非超過確率 $90 \%$ のスペクトルに最も一致度の高い波 形を抽出した。最終的に抽出された時刻歴波形とその波 形の所要降伏震度スペクトルを図-14, 図-15に示す.こ こでの所要降伏震度スペクトル算定時の減衰定数として は, 鉄道橋梁の地震応答算定時の減衰定数 $(\mathrm{h}=0.04 / \mathrm{T}(0.10 \leqq \mathrm{~h} \leqq 0.20))$ を用いている5 . 図-15より， 抽出された波形の所要降伏震度スペクトルは，概ね全周
期帯域において非超過確率90\%のスペクトルを包絡して おり，図-14の時刻歴波形を用いることで非線形応答と してもある程度大きな応答を考えた上での設計を行うこ とが可能であることが見て取れる.

また今回選択されたスペクトルாの時刻歴波形はCase6 のSiteBによる結果であり，アスペリティによる破壊が 進行する方向に位置していることが分かる.さらにサイ 卜特性の変化は0.1倍とした場合であり，いずれも本検 討において構造物の非線形応答量が大きくなる傾向があ る地点における結果となっている，スペクトルIにおい てもCase2のSiteRは破壊伝播効果の影響が大きい地点, サイト特性も0.2倍とそれぞれ $t_{g r}^{O}(\omega)$ の振動数毎の変化 が小さくなる傾向が強い位相特性が選択されている.

さらに本手法においては，スペクトルாとスペクトルI を比較すると，震源特性，伝播経路特性ともにスペクト ルIIの方が $\mu_{t g r}(\omega), \sigma_{t g r}(\omega)$ の值が小さくなっているこ とは明らかであり，これまでの検討結果から非線形応答 量が大きくなる傾向の位相を用いていると言える．弾性 
加速度応答スペクトル（図-1）は全周期帯においてスペ クトルIの方が大きいかもしくは同等となっているため, 位相，振幅ともにスペクトルாの方が非線形応答量が大 きくなる地震動を設定していることになる。つまり繰り 返し応答による損傷の累積を無視した場合には，スペク トルIの方が必ず損傷程度が大きくなる地震動となって いると言える．これは図-15の(a)>(b)となっていることか らも確認される.

\section{6. まとめ}

本研究では位相特性の変化が構造物の非線形応答に与 える影響を把握することを目的として，想定される範囲 内の位相特性と同一の弾性加速度応答スペクトルを有す る時刻歴波形を多数作成し，各波形の

構造物非線形忘答量を所要降伏震度スペクトルという形 で表現し，得られた結果をもとに考察を行った，その結 果，以下の知見を得た。

・弾性加速度応答スペクトルが等しい時刻歴波形であっ ても, 位相の各特性の変化によって非線形応答が大き く変化する．またこの応答の変動は応答塑性率2.0以 上では，構造物の非線形性の程度には依存せず，構造 物応答が弾性範囲か非線形範囲かによって大きく変化 する. 位相の変化に伴う応答の変動係数は0.1程度で ある。

・位相のサイト特性が構造物応答に与える影響を確認し たところ, サイト特性の群遅延時間が大きくなるほど 非線形応答量が小さくなることが分かった。 つまり対 象と寸る地盤の条件が等しい場合にも, 深部構造の差 によって構造物の非線形応答量が大きく変化し，構造 物を設計する場合にも，今回想定した範囲のサイト特 性の違いによって, 構造物に要求される降伏震度が 5\%程度変化する．またこのバラツキも構造物の非線 形性の大きさにそれほど依存しない.

・位相の震源特性が構造物応答に与える影響は, ディレ クティビティーの影響が大きい地点ほど非線形応答が 大きくなる傾向があることを示した。この震源特性の 差によって構造物に要求される性能として降伏震度が 1割程度変化する可能性があることも明らかにした.

- 位相特性の変化を考慮した設計地震動選択の例として, 今回作成した地震動群の中から一定非超過確率を満足 する時刻歴波形を抽出した. この時刻歴波形を用いる ことで，非線形応答の観点からもある程度大きな応答 を想定した上での構造物の設計を行うことが可能であ ると考えられる.

以上のように構造物の非線形応答に与える位相特性の影 響は大きい，構造物の耐震設計を念頭に置いた強震動予
測を行う場合には，これら位相特性の不確定性を適切に 評価し, 構造物の応答が過小評価となることのないよう 注意する必要がある.

謝辞 : 一部の図の作成には，GMT $\mathrm{GM}^{21)}$ 用いました，記し て謝意を表します。

\section{参考文献}

1）（社）日本港湾協会 : 港湾の施設の技術上の基準・同解 説, 2007.

2) 大阪府 : 大阪府平成19 年度想定標準地震動添付資料, 2007.

3) 大西良広, 鈴木恭平, 田中和樹, 林康裕 : 上町断層近傍 の設計用地震荷重設定に考慮す心゙き断層パラメータ，日 本建築学会構造系論文集, No.665, pp.1263-1270, 2011.

4)（社）日本道路協会 : 道路橋示方書・同解説（ $\mathrm{V}$ 而震設 計編)，2002.

5) (財) 鉄道総合技術研究所 : 鉄道構造物等設計標準・同 解説 而震設計, 1999.

6) 佐藤忠信, 室野剛隆，西村昭彦：震源・伝播・地点特性 を考慮した地震動の位相スペクトルのモデル化，土木学 会論文集，No.612/-46，pp.201-213，1999.

7) 佐藤忠信, 室野剛隆, 西村昭彦 : 観測波に基づく地震動 の位相スペクトルのモデル化，土木学会論文集，No.640/50, pp.119-130, 2000.

8）室野剛隆, 川西智浩, 坂井公俊 : 位相のインバージョン に基づく地震波形合成法，鉄道総研報告，Vol.23，№.12， p.5-10, 2009.

9) 坂井公俊, 室野剛隆, 澤田純男 : 地震基盤深度を考 慮したレベル2地震動の簡易評価, 第12回地震時保有 耐力法に基づく橋梁等構造の耐震設計に関するシン ポジウム講演論文集, pp.317-322, 2009.

10）澤田純男，盛川仁，土岐憲三，横山圭樹 : 地震動の位相 スペクトルにおける伝播経路・サイト特性の分離, 第10 回日本地震工学シンポジウム論文集, pp.915-920, 1998.

11）入倉孝次郎：強震動予測レシピー大地震による強震動の 予測手法一, 京都大学防災研究所年報, 47A, 2004.

12）地震調查研究推進本部地震調查委員会 : 震源断層を特定 した地震の強震動予測手法（「レシピ」）, http:/www.jishin.go.jp/main/kyoshindo/08apr_kego/recipe.pdf, 2008.

13）地震調查研究推進本部 地震調查委員会：「全国を概観し た地震動予測地図」報告書 分冊2, 2005.

14）武村雅之：日本列島における地款内地震スケーリング則 一地震断層の影響および、地震被害との関連 - , 地震第2 輯, Vol.51, No.2, pp.211-228, 1999.

15）大崎順彦 : 新・地震動のスペクトル解析入門，鹿島出版 会, 1994.

16）荒川直士，川島一彦，相沢興 : 応答スペクトル特性を調 
整した時刻歴地震応答解析用入力地震動波形，土木技術 資料，第26巻，第7号，1984.

17) Veletsos, A. S., Newmark N. M. and Chelapati C. V.: Deformation spectra for elastic and elastoplastic systems subjected to ground shock and earthquake motions, Proc. of 3th World Conference on Earthquake Engineering, New Zealand, Vol. II, pp. 663-680, 1965.

18) 西村昭彦, 室野剛隆，齋藤正人 : 所要降伏震度スペクト ルの作成と耐震設計への適用，地震時保有耐力法に基づ く橋梁の而震設計に関するシンポジウム講演論文集, Vol. 3, pp.43-48, 1999.

19) Clough, R. W. and Johnston S. B. : Effect of stiffness degradition on earthquake ductility requirements, 第2回日本地震工学シンポジウ
么梗概集, pp.227-232, 1966.

20) 坂井公俊, 室野剛隆 : 構造物の非対称応答特性と地震動 特性の関係，土木学会論文集A1（構造・地震工学）, Vol.65, No.1, pp.325-332, 2009.

21) Wessel, P., and Smith, W.H.F. : New improved version of Generic Mapping Tools released. EOS, Trans. AGU, 79, 579, 1998.

(2011. 12. 16 受付, 2011.3.2 修正, 2011. 3.6 受理)

\section{FUNDAMENTAL STUDY ON THE VARIABILITY OF STRUCTURAL NONLINEAR RESPONSE DUE TO THE UNCERTAINTY OF PHASE SPECTRUM}

\section{Kimitoshi SAKAI and Yoshitaka MURONO}

In this study, the effect of uncertainty of phase characteristics of earthquake on variability of structure's nonlinear response was investigated. It is clarified that variation of nonlinear response is significant, and it is conspicuous as natural period of structure becomes longer. It consequently follows that the effect of uncertainty of phase characteristics should be properly taken into account when the estimation of strong ground motion is conducted for making design earthquake motion. 